\title{
Penyampaian Aspek Keperilakuan Akuntansi dalam Kurikulum
}

\section{Drajat Armono*}

\begin{abstract}
Behavioral Accounting as the subject began to be implemented in some universities. However there are some differences of opinion in both the delivery and the willingness to put it into the college curriculum. This paper aims to provide an alternative way of delivering the behavioral aspects of accounting if the material is incorporated into the curriculum. Authors reasoned take the title as given that all of science will lead to behavioral in their respective fields. In other words, all areas would ultimately lead to behavioral aspects to better understand the essence of the existing knowledge in the field.

Accounting as a branch of science that need to understand the meaning behind each decision made by both individuals and organizations. By developing behavioral aspects, allows accounting to be learned up to the highest level in the world of education. This paper also provides an alternative behavioral development in the accounting curriculum, namely (1) Behavioral Accounting incorporated as a special course in the accounting curriculum, and (2) behavioral aspects or components incorporated as an integral part of any accounting course.
\end{abstract}

\section{Key words :}

\section{Pendahuluan}

Mengingat usulan dari Indriyantoro (1999) pada Jurnal Bisnis dan Akuntansi terbitan STIE Trisakti, sudah saatnya dunia pendidikan akuntansi untuk mulai memasukkan aspek keperilakuan kedalam kurikulum dengan $\mid$ mendorong para pengajar untuk memasukkan unsur akuntansi keperilakuan sebagai komponen mata kuliahnya. Beranjak dari pemikiran tersebut, penulis berpandangan bahwa ususlan tersebut sangatlah menarik untuk ditindaklanjuti secara nyata. Menurut Caplan (1989), pemikiran akuntansi keperilakuan terdapat di semua bidang

"Dosen Fakultas Ekonomi UII 
akuntansi, baik akuntansi keuangan, akuntansi manajerial, akuntansi sumber daya manusia, pengauditan, akuntansi sosial, serta sistem informasi akuntansi dan pengolahan informasi manusia. Kusuma (2003) mempunyai pendapat yang sedikit berbë̉a mengenai istilah akuntansi keperilakuan. Beliau merasa bahwa istilah "aspek perilaku dalam akuntansi" lebih tepat dibanding istilah "akuntansi keperilakuan" dengan alasan untuk menghindari kesan adanya bidang ilmu baru yang setara dengan akuntansi keuangan dan akuntansi manajemen. Menurut Kusuma (2003), aspek perilaku dalam akuntansi mencakup seluruh bidang akuntansi, baik akuntansi keuangan, akuntansi manajemen, akuntansi sektor publik, sistem informasi akuntansi, dan pengauditan.

Penulis lebih sepakat dengan pendapat Kusuma (2003) untuk menghindari kesan adanya cabang ilmu baru dalam akuntansi. Namun dalam tulisan ini penulis tidak membicarakan pertentangan istilah "akuntansi keperilakuan" atau "aspek perilaku dalam akuntansi", akan tetapi lebih memfokuskan pada penawaran alternatif cara penyampaian materi keperilakuan dalam kurikulum perguruan tinggi.

\section{Keterbatasan Pemahaman Mahasiswa Mengenai Aspek Perilaku dalam Akuntansi}

Meskipun mahasiswa telah banyak memperoleh berbagai materi akuntansi, akan tetapi pada tahap tugas akhir, khususnya pada saat mempresentasikan hasil analisis data, terkadang mahasiswa sekedar mengungkapkan angka dari hasil analisis data dan kurang dalam penginterpretasian data secara lebih luas karena mengabaikan aspek perilaku dari apa yang terjadi dan yang seharusnya dari hasil penelitian tersebut. Terlebih lagi pada saat mahasiswa memasuki dunia kerja atau dunia usaha, mereka terkadang mengalami kesulitan dalam pengambilan keputusan yang berkaitan dengan aspek perilaku, baik secara organisasi maupun secara individu.

Walaupun aspek perilaku telah diberikan dalam mata kuliah perilaku organisasi, tetapi bobotnya terkesan masih kurang memadai dalam menjelaskan perilaku individu dan organisasi pada saat bersinggungan dengan akuntansi. Hal tersebut menyebabkan mahasiswa cenderung tidak menyadari adanya aspek perilaku dalam akuntansi. Para lulusan perguruan tinggi dari jurusan akuntansi bagi kaum awam masih dianggap hanya mampu menghitung angka saja, dan kurang mampu dalam proses pengambilan keputusan. Hal tersebut membawa kesan seolah-olah pekerjaan lulusan akuntansi hanya berkaitan dengan masalah administrasi keuangan belaka. Faktanya, selain pihak manajemen, bidang akuntansi juga sangat berperan dalam menentukan keputusan karena berkaitan dengan alokasi sumber daya manusia yang dimiliki oleh perusahaan. 
Atas dasar itulah penulis sepakat dengan usulan yang disampaikan oleh bérbagai pakar, misal Segel (1989), Caplan (1989), Belkaoui (1989), Indriantoro (1999), serta Kusuma (2003) yang menyarankan perlunya aspek perilaku dalam akuntansi diberikan pada mahasiswa akuntansi.

\section{Pengembangan Materi Aspek Perilaku dalam Akuntansi}

Perhatian terhadap aspek perilaku dalam akuntansi mulai berkembang sejak adanya penelitian yang dilakukan oleh Argyris (1953) mengenai|pentingnya partisipasi dalam penginternalisasian anggaran dan peran anggaran sebagai motivator bagi manajer. Kemudian barulah pada tahun 1971 AAA melalui Committee on Behavioral Science Content of the Accounting Curriculum merekomendasikan supaya akuntan akademik segera memasukkan materi yang relevan dari ilmu keperilakuan kedalam kurikulum akuntansi (AAA, 1971).

Beberapa tahun kemudian muncul buku-buku yang mencoba membahas aspek keperilakuan, seperti kumpulan artikel yang diedit oleh Schiff dan Lewin (1974), Hopwood (1974), Siegel dan Ramanauskus-Marconi (1989), Belkaoui (1989), Parker dkk (1989). Siegel (1989) mengatakan bahwa aspek perilaku dalam akuntansi merupakan penghubung antara akuntansi dengan ilmu sosial yang menekankan pada bagaimana perilaku manusia dalam mempengaruhi data akuntansi dan keputusan bisnis. Selain itu, menekankan pula pada bagaimana informasi akuntansi mempengaruhi keputusan bisnis dan perilaku manusia. Membicarakan aspek perilaku sangatlah menarik terlebih yang berkaitan dengan akuntansi, karena aspek perilaku dalam akuntansi berperan penting untuk meneliti serta memahami bagaimana berperilaku dan memandang pekerjaan, perusahaan, teman sekerja, maupun lingkungan sosial secara luas.

\section{Pemahaman Mahasiswa Mengenai Aspek Perilaku dalam Akuntansi}

Memperkenalkan perkembangan aspek perilaku dalam akuntansi merupakan salah satu cara untuk menambah pemahaman mengenai alasan mengapa aspek perilaku lebih banyak diimplemetasikan pada penelitian empiris. Menurut Belkaoui (1989) penetapan perilaku dalam akuntansi berkaitan dengan perilaku manusia yang menghubungkan informasi akuntansi dan berbagai permasalahannya. Hal tersebut yang menjadi konsep dasar untuk menjelaskan dan memprediksi perilaku manusia yang diberikan pada semua kemungkinan dalam konteks akuntansi.

Dengan mempelajari berbagai kesulitan dalam riset aspek perilaku dalam akuntansi dapat memberikan pemahaman kepada mahasiswa bahwa aspek perilaku mempunyai suatu keunikan terlebih dalam penetapan keputusan yang berkaitan dengan akuntansi karena aspek perilaku sangat erat kaitannya dengan penelitian empiris, hal tersebut senada dengan yang dikemukakan David dan Sundem (1989). 
Adapun kesulitan-kesulitan tersebut antara lain:

1. Bidang perilaku yang sangat luas, yang menjadikan sangat kecil kemungkinan pengembangan teori jika mengintegrasikan semua penelitian keperilakuan. Walaupun Behavioral Accounting Research, yang selanjutnya penulis sebut BAR, mempunyai basic khusus tentang aspek perilaku manusia, tetapi sedikit integrasinya dengan bidang lain.

2. Kesulitan dalam membedakan variabel-variabel yang relevan pada keperilakuan dan bentuk hubungan antar variabel tersebut dalam satu teori. Kesulitan dalam menetapkan konstruk pada penelitian dan kesulitan dalam mengukur proksi dari suatu konsep.

3. Adanya trade-off antara validitas internal dan eksternal, karena BAR selalu berada pada suatu standar yang menggunakan kedua validitas tersebut.

4. Sulitnya dalam menilai secara kuantitatif, karena konsep tersebut sulit untuk diukur dan diobservasi sehingga harus menggunakan indikator yang dapat menjelaskan fenomena-fenomena yang terjadi, dalam hal ini penilaian dilakukan secara kualitatif.

Disamping itu dapat pula membekali mahasiswa dengan memperkenalkan peran riset keperilakuan dalam pendidikan akuntansi manajemen sesuai dengan perkembangan terkini. Binberg (2000) mengatakan pentingnya keperilakuan dalam materi kurikulum akuntansi manajemen dengan menawarkan dugaan bentuk materi seperti yang akan diberikan kepada mahasiswa. Lebih jauh lagi memperkenalkan pokok bahasan akuntansi manajemen terutama yang berkaitan dengan teknik seperti penentuan biaya produksi oleh akuntan yang dapat mengumpulkan dan mengkomunikasikan data sehingga manajer perusahaan dapat membuat keputusan yang terbaik dan akurat.

Bahan kajian "Three Decades of Behavioral Accounting Research: A Search for Order" yang ditulis oleh Binberg dan Shields (1989) dapat membekali mahasiswa dalam mengenalkan betapa pentingya BAR diberikan pada mahasiswa karena mengupas secara mendalam mengenai karakteristik BAR, aliran BAR, serta disiplin ilmu pendukung yang tepat. Hal tersebut akan menambah bekal mahasiswa karena dengan mempelajari aspek keperilakuan dapat menambah wawasan mahasiswa dalam mempertimbangkan pengambilan keputusan. Karena artikel tersebut juga menyinggung teori yang mendasari dalam mempelajari BAR yaitu antarallain Teori Organisasi, Psikologi, Sosiologi, Ekonomi, serta Politik.

Menurut Indriantoro (1999), menggunakan materi akuntansi manajemen dari Caplan (1989) atau Hansen dan Mowen (1997) dapat pula menambah wawasan dalam mempelajari berbagai kasus, terlebih yang berkaitan dengan aspek perilaku manajer dalam mengambil keputusan, karena kedua buku tersebut banyak membahas kasus-kasus serta menggunakan pendekatan teori agensi dan dilakukan secara terpisah dalam tiap babnya. Bahkan Indriantoro (1999) mengatakan adanya 
perkembangan yang cukup menggembirakan karena beberapa buku ajar terutama yang berkaitan dengan akuntansi manajemen telah banyak membahas aspek keperilakuan walaupun dalam bab terpisah, seperti yang telah dilakukan oleh Hirsch (1994), dan juga Anthony dan Govindarajan (1995).

\section{Memperluas Perspektif Mahasiswa}

Satu diantara hal-hal yang paling sulit dalam mempelajari ilmu pengetahuan adalah arti dan penggunaan istilah khusus yang diberikan oleh ilmuwan sehari-hari. Hal ini berkaitan dengan pemahaman dalam mempelajari bahasa ilmuwan sosial (Kerlinger, 2003). Oleh karena itu pengajar akuntansi seharusnya juga memahami tentang berbagai kemampuan teknis dan metodologi khususnya yang berkaitan dengan ilmu sosial, karena hal tersebut berkaitan erat dengan perluasan penyampaian materi akuntansi pada mahasiswa terlebih pemahaman tentang aspek perilakunya.

Adanya perdebatan aspek perilaku dalam akuntansi bukan merupakan bidang akuntansi melainkan bidang psikologi atau organisasional menjadikan pandangan yang salah. Kusuma (2003) mengatakan, menjadi hal yang sangat ironis karena sesungguhnya selama ini bidang akuntansi keperilakuan justru diambil alih oleh bidang lain, dikarenakan ketidakmampuan akuntan untuk menanganinya. Untuk mengatasinya sangat diperlukan pemberian materi aspek perilaku dalam akuntansi kepada mahasiswa dengan mempertimbangkan kemungkinan alternatif penyampaian materi apakah secara terpisah pada materi tersendiri atau memasukkannya sebagai komponen mata kuliah akuntansi.

Hal yang perlu diperhatikan pada perspektif aspek perilaku dalam akuntansi sangat mendasari pada kemampuan mahasiswa dalam menginterpretasikan data akuntansi. Terlebih hal tersebut ditegaskan oleh komite akuntan yang merekomendasikan agar akuntan akademik (akuntan pendidik) segera "mengambil tanggung jawab kurikulum akuntansi" (AAA, 1971). Siegel (1989) berpendapat bahwa pengakuan hubungan antara perilaku dan pengukuran akuntansi mengubah definisi akuntansi yang konvensional. Hal ini juga menggeser pengertian akuntansi yang menjelaskan tentang pengukuran dan komunikasi data ekonomi pada berbagai pembuatan keputusan dan komunikasi data ekonomi pada berbagai tujuan pembuatan keputusan serta tujuan perilaku lain.

Lebih jauh lagi perilaku akuntan yakin bahwa tujuan utama laporan akuntansi adalah mempengaruhi perilaku untuk memotivasi tindakan yang diinginkan, semisal perusahaan mungkin berhasil mencapai anggaran karena kinerja organisasi yang baik atau tidak berhasil dikarenakan karyawan bekerja dengan tujuan yang bertentangan. Jadi bentuk kandungan laporan anggaran memacu produktivitas karyawan dan membuat karyawan bekerjasama atau mungkin menciptakan konflik internal serta membunuh inisiatif (Siegel, 1989). 


\section{Pertentangan Pendapat Mengenai Penyampaian Materi Aspek Perilaku dalam Akuntansi}

Adanya saran dari AAA (1971) bahwa akuntansi pada hakikatnya adalah proses keperilakuan, maka akuntan pendidik seharusnya memasukkan aspek perilaku dalam kurikulum akuntansi. Hal tersebut menimbulkan perdebatan apakah aspek perilaku tersebut diajarkan sebagai komponen mata kuliab akuntansi baik pada akuntansi manajemen, akuntansi keuangan, sistem informasi akuntansi, dan pengauditan atau sebagai alternatif aspek keperilakuan pada mata kuliah tersendiri (Caplan, 1989, Indriantoro, 1999). Untuk meninjau lebih jauh lagi, penulis mengilustrasikan kedua alternatif tersebut sebagai berikut:

\section{Mata Kuliah Khusus pada Akuntansi Keperilakuan}

Indriantoro (1999) mengatakan pengajaran aspek perilaku dalam mata kuliah tersendiri memiliki keunggulan, bahwa mahasiswa dapat menerima penjelasan atau dapat mendiskusikan aspek perilaku tersebut secara terpadu. Pengajar dimungkinkan membahas secara mendalam mengenai teori-teori keperilakuan dan menghubungkannya secara langsung dengan topik akuntansi yang mengandung aspek perilaku. Pendekatan tersebut sekaligus juga untuk menutup kekurangan tidak ditekankannya aspek perilaku pada mata kuliah akuntansi yang sebelumnya pernah diambil oleh mahasiswa. Kelemahan pendekatan ini adalah menjadikan mata kuliah ini semacam mata kuliah capitaselecta, karena pengajar harus mengajarkan aspek keperilakuan untuk hampir semua bidang akuntansi yang terkadang dapat menimbulkan pemahaman yang keliru bahwa bidang lain tidak mengandung aspek perilaku. Sehingga pemahaman aspek keperilakuan meskipun merata pada semua bidang, tetapi akhirnya tidak dapat dipahami secara mendalam dan terkadang sulit untuk mempertahankan tingkat perhatian mahasiswa yang sama untuk setiap topik.

\section{Aspek Perilaku sebagai Komponen Mata Kuliah Akuntansi}

Pada pendekatan ini aspek keperilakuan sebagai komponen mata kuliah akuntansi mempunyai keuntungan bahwa mahasiswa lebih mudah mengkaitkan aspek keperilakuan untuk topik akuntansi tertentu pada saat topik tersebut dibahas. Misal pada saat membahas topik penggunaan Return on Investment (ROI) sebagai tolok ukur kinerja pusat investasi, maka pengajar mata kuliah sistem pengendalian manajemen dapat menekankan konsekuensi disfungsional penggunaan ROI tersebut. Demikian pula pada saat membahas penganggaran dapat dibahas keuntungan penggunaan sistem yang bersifat partisipatif maupun kemungkinan timbulnya budgetary slack karena penggunaan sistem yang sama. 
Selain itu penyampaian materi dengan cara memasukkan dalam komponen dirasa lebih sederhana, ringkas dan tepat sasaran. Disisi lain pendekatan tersebut di atas juga memiliki kelemahan yaitu aspek keperilakuan sebagai komponen yang melekat pada mata kuliah akuntansi secara umum terkadang pengajar mata kuliah teirsebut tidak cukup waktu untuk menekankan aspek tersebut. Lebih sulit lagi apabila pengajar tersebut tidak memiliki apresiasi terhadap aspek keperilakuan. Menurut Indriantoro (1999), kemungkinan terdapat kesulitan untuk mengharapkan dosen-dosen akuntansi di Indonesia agar menekankan aspek keperilakuan dalam pengajaran mereka. Jikapun diberikan, masih sedikit pemahaman dari mahasiswa tentang aspek keperilakuan tersebut, karena ditengarai tidak diberikannya aspek keperilakuan pada mata kuliah akuntansi konvensional secara umum. Penyampaian aspek perilaku, menurut penulis, yang paling tepat pada mahasiswa akuntansi adalah dalam bentuk pemberian kasus, sedangkan kasus tersebut lebih banyak tersedia pada jurnal penelitian empiris, misal Behavioral Research in Accounting, Accounting Organization on Society, Journal of Accounting Research, The Accounting Review, dan untuk Indonesia yaitu Jurnal Riset Akuntansi Indonesia, walaupun jurnal-jurnal lain secara implisit juga terkadang memasukkan unsur keperilakuan akan tetapi sebagian besar ter-cover dalam jurnal tersebut di atas (Kusuma, 2003).

Apabila mempertimbangkan manfaat pemberian aspek perilaku dalam akuntansi, seharusnya tidak perlu dijadikan alasan bahwa karena lebih banyak terdapat pada penelitian empiris, maka materi akuntansi keperilakuan hanya dijadikan mata kuliah pilihan bagi mahasiswa, dan bahkan kemungkinan justru ditiadakan. Bahkan jika kita mengkaji lebih jauh manfaatnya sebenamya justru dapat dijadikan sebagai bekal awal atau dasar dalam memahami mata kuliah akuntansi keperilakuan bagi mahasiswa yang melanjutkan studi ke jenjang yang lebih tinggi. Hal tersebut di atas yang kemungkinan menjadikan perbedaan pemberian materi aspek keperilakuan, menurut Indriantoro (1999), karena kebanyakan di penelitian empiris terdapat materi aspek keperilakuan sehingga penawaran akuntansi keperilakuan diselenggarakan pada jenjang $S 1$, terutama pada jenjang S2, itupun pada konsentrasi Akuntansi Manajemen.

Penutup

Tiap-tiap alternatif cara penyampaian materi mempunyai kelebihan dan juga kekurangan, akan tetapi tuntutan perkembangan yang ada sekarang dirasa sesuai jika penyampaian materi aspek perilaku dalam akuntansi dimasukkan sebagai komponen mata kuliah akuntansi. Untuk mengatasi kelemahan pendekatan ini, tenaga pengajar diharapkan lebih banyak menyediakan waktu dan meningkatkan kemampuan apresiasi serta pemahaman aspek perilaku dalam topik yang diajarkan. 


\section{DAFTAR PUSTAKA}

American Accounting Association, (1971). Report of the Committe on Behavioral Science. Content of the Accounting Curriculum. Accounting Review. (supplement to vol XLVI), p. 247-285.

Anthony, Robert N., dan Vijay Govindarajan, (1995). Management Control Systems, $8^{\text {th }}$ Edition, Chicago: Irwin.

Argyris, Chris, (1953), "Human Problems with Budget". Harvard Business Review. January-February.

Belkaoui, Ahmed, (1989). Behavioral Accounting: The Reserach and Practical Issues, New York: Quorum Book.

Binberg, Jacob G, dan Jeffrey F. Shields, (1989). "Three Decades of Behavioral Accounting Research: A Search for Order". Behavioral Research in Accounting, Vol. 1, June, p. 23-74.

Binberg, Jacob G, (2000),"Role of Behavioral Research in Management Accounting Education in The $21^{\text {st }}$ Century,"Issues in Accounting Education. Vol. 15, (4): 696-712.

Burgstahler, David, dan Gery L., Sundem, (1989)."The Evolution of Behavioral Accounting Research in The United States 1968-1987". Behavioral Research in Accounting, Vol. 1, June, p. 75-108.

Caplan, Edwin H., (1989)."Behavioral Accounting - A Personal View". Behavioral Research in Accounting, Vol. 1, June, p.109-123.

Hansen, Don R., dan Maryanne M. Mowen, (1997). Management Accounting $4^{\text {th }}$ Edition, Cincinnati, OH: South-Western College Publishing.

Hirsch, Maurice L., (1994). Advance Management Accounting. $2^{\text {nd }}$ Edition, Cincinnati, $\mathrm{OH}$ : South-Western College Publishing.

Hopwood, Anthony, (1974). Accounting and Human Behavior. Prentice Hall: Engelwood Cliff, NJ.

Indriantoro, N., (1999),"Mata Kuliah Akuntansi Keperilakuan dalam Kurikulum Strata 1 di jurusan Akuntansi". Jurnal Bisnis dan Akuntansi STIE Trisakti Jakarta, Vol. 1, April.

Kerlinger F, N., (2003). Asas-asas Penelitian Behavioral. Gadjah Mada University Press, Juli.

Kusuma, Indra W, (2003),"Topik Penelitian Akuntansi Keperilakuan". Behavioral Research in Accounting (BRIA), working paper di STIE Trisakti Jakarta.

Paker, Lee D., Kenneth R Ferris, dan David T. Outley, (1989). Accounting for the Human Factor. Prentice Hall: New York.

Schiff, Michael dan Arie Y. Lewin, (1974). Behavioral Aspect of Accounting. Prentice Hall: Engelwood Cliff, NJ.

Siegel, Gary, dan Heleneramanauskas-Marconi, (1989). Behavioral Accounting. SouthWestern Publishing Co: Cincinnati, $\mathrm{OH}$. 